\title{
Pemahaman Nasionalisme Santri Siswa di SMP Al-Uswah Semarang
}

\author{
Rina Wasini, Arif Purnomo, Aisyah Nur Sayidatun Nisa ${ }^{\bowtie}$ \\ Social Science Education Department, Faculty of Social Science, Universitas Negeri Semarang, \\ Indonesia
}

\section{Info Artikel}

Sejarah Artikel:

Disubmit Januari 2019

Direvisi : Februari 2019

Diterima: Maret 2019

\section{Keywords:}

effectiveness, show and tell

learning method, social

science's learning output

\begin{abstract}
Abstrak
Pembelajaran yang efektif tidak terlepas dari proses pembelajaran yang berkualitas. Untuk mencapai pembelajaran yang berkualitas diperlukan perencanaan, pelaksanaan, dan evaluasi dari seorang guru. Salah satu peran guru sebelum melaksanakan pembelajaran adalah memilih model pembelajaran yang tepat untuk mendorong siswa agar hasil belajar baik. Model pembelajaran yang tepat untuk memacu hasil belajar siswa adalah model pembelajaran show and tell. Tujuan peneltian adalah: (1) menjelaskan hasil belajar IPS peserta didik dengan menggunakan model pembelajaran show and tell, (2) menjelaskan hasil belajar IPS peserta didik yang menggunakan ceramah, dan (3) menganalisis perbedaan yang signifikan antara hasil belajar IPS peserta didik yang menggunakan model pembelajaran show and tell dan yang menggunakan ceramah. Metode penelitian adalah eksperimen semu (quasi eksperiment). Pengumpulan data menggunakan tes dan dokumentasi. Analisis data menggunakan uji-T pada program SPSS seri 16.0 for windows. Hasil penelitian diperoleh simpulan bahwa pembelajaran IPS dengan menggunakan model pembelajaran show and tell lebih efektif dibandingkan dengan menggunakan ceramah. Hal ini ditunjukkan dengan nilai rata-rata hasil belajar siswa yang mengikuti pembelajaran IPS menggunakan model pembelajaran show and tell yaitu 7,25 lebih tinggi dari nilai rata-rata hasil belajar siswa yang mengikuti pembelajaran dengan ceramah yaitu 6,31 .
\end{abstract}

\begin{abstract}
An effective learning can not be separated with a qualified learning process. It needs plan, implementation, and evaluation from a teacher to achieve the qualified learning process. One of the teacher's tasks before conducting a certain learning is choosing an appropriate learning method to encourage the students in order to achieve a good learning output. The appropriate learning method to encourage the students' learning output is show and tell method. The objectives of this research are: (1) to explain the learning output of social science's students with the use of show and tell learning method, (2) to explain the learning output of social science's students with the use of leaturing method, and (3) to analyse the significant differences between the learning output with the use of show and tell learning method and leaturing method. The method of this research is quasi experimental method. Tests and documentations are used to collect the data. T-test in SPSS program series 16.0 for windows is used to analyse the data. From the research, it can be concluded that social science's learning using show and tell learning method is more effective than using leaturing method. It is shown in the average score of students' learning output which followed sosial science's learning using show and tell learning method is 7,25, higher than the average score of students' learning output which followed leaturing method which is 6,31 .
\end{abstract}

(C) 2019 Universitas Negeri Semarang

\footnotetext{
Alamat korespondensi:

Gedung C1 Lantai 1 FIS Unnes

Kampus Sekaran, Gunungpati, Semarang, 50229

E-mail: jurnalsosioliumpips@mail.unnes.ac.id
} 


\section{PENDAHULUAN}

Sapriya, dkk. (2006:3) menjelaskan bahwa IPS adalah perpaduan dari konsepkonsep ilmu sosial seperti sejarah, geografi, ekonomi dan sebagainya yang diperuntukkan bagi pembelajaran pada tingkat persekolahan. Tujuan dari pembelajaran IPS adalah mengembangkan siswa untuk menjadi warga negara yang memiliki pengetahuan, sikap, dan keterampilan yang memadai untuk berperan serta dalam kehidupan demokrasi dimana konten mata pelajarannya digali dan diseleksi berdasarkan sejarah dan ilmu sosial, serta banyak hal termasuk humaniora dan sains (Sapriya, dkk., 2007:13).

Sementara itu, pemberlakuan Kurikulum 2013 telah membawa perubahan dalam pembelajaran IPS di SMP. Diterapkannya pembelajaran terpadu pada mata pelajaran IPS jenjang SMP tentu dapat menimbulkan kesulitan-kesulitan tersendiri. Pertama, para guru IPS belum memiliki pengalaman yang cukup dalam menerapkan pendekatan terpadu sebagai akibat pemberlakuan kurikulum sebelumnya. Kedua, guru-guru mata pelajaran IPS di sekolah sebagian besar memiliki latar belakang ke-IPS-an yang monolitik, yaitu berasal dari lulusan pendidikan geografi, pendidikan sejarah, pendidikan ekonomi, dan pendidikan sosiologi. Guru harus mampu memahami karakteristik peserta didik dan memberikan rangsangan kepada peserta didik agar bersemangat dalam mengikuti proses pembelajaran IPS di sekolah. Selain itu, guru harus memiliki kemampuan yang mendalam tentang bahan yang diajarkan dalam mengkomunikasikan pengetahuan kepada peserta didiknya.
Kenyataannya, berdasarkan hasil observasi dan wawancara yang telah dilakukan peneliti pada tanggal 30 Juli - 3 Agustus 2017 terhadap guru IPS di SMP Islam Sudirman Ambarawa diperoleh data bahwa proses pembelajaran IPS yang telah dilaksanakan selama ini belum sesuai dengan yang diharapkan. Kegagalan pembelajaran bisa disebabkan oleh beberapa faktor. Faktor tersebut bisa dari guru, siswa, metode yang digunakan, kurangnya pemanfaatan media, maupun evaluasi yang tidak tepat. Menurut pengalaman tahun sebelumnya peserta didik mengalami kesulitan pada mata pelajaran IPS, bahkan nilai ujian semester ganjil tahun ajaran 2016/2017 adalah 50\% peserta didik belum mencapai KKM. Hasil ulangan tengah semester gasal juga belum memenuhi standar KKM pada sekolah tersebut. Rendahnya hasil belajar peserta didik merupakan masalah dalam pembelajaran IPS. Hal ini disebabkan karena guru yang belum menerapkan model, metode, dan strategi pembelajaran dengan baik.

Pada saat berlangsungnya proses pembelajaran IPS, guru masih menerapkan metode pembelajaran yang monoton yaitu ceramah. Dimana guru menerangkan, peserta didik duduk, mencatat, dan mendengarkan apa yang disampaikan guru sehingga ketika peserta didik diminta untuk bertanya oleh guru banyak yang tidak melakukannya hingga proses belajar mengajar berakhir tanpa ada kesempatan untuk mengembangkan daya kreatifitas yang dimiliki peserta didik. Peserta didik kelas VII SMP Islam Sudirman Ambarawa kurang berminat mengikuti pembelajaran IPS karena dianggap membosankan. Pada saat guru menjelaskan materi, banyak peserta didik yang mengobrol dengan teman sebangkunya, mengantuk, bosan, dan banyak yang izin ke kamar kecil. Hal tersebut dikarenakan guru menggunakan 
metode ceramah. Selain itu, setelah guru selesai menjelaskan materi pelajaran, peserta didik diberi kesempatan bertanya namun tidak ada yang bertanya karena mereka malu dan takut salah. Dengan kondisi seperti itu, proses pembelajaran yang dilakukan cenderung pada pencapaian target materi kurikulum, dan lebih mementingkan pada penghafalan konsep bukan pada pemahaman. Suasana pembelajaran menjadi tidak kondusif, minat belajar dan aktifitas peserta didik dalam pembelajaran IPS masih sangat kurang, sehingga proses dan hasil belajar juga rendah.

Proses pembelajaran dan hasil belajar IPS yang rendah merupakan suatu permasalahan yang harus segera diatasi. Proses pembelajaran pada dasarnya sama dengan proses komunikasi, yaitu proses beralihnya pesan dari suatu sumber, menggunakan saluran, kepada penerima, dengan tujuan untuk menimbulkan akibat atau hasil (Gafur dalam Jurnal Harmoni Sosial yang ditulis oleh Fahmadia dan Mukminan, 2016:29). Dalam usaha mendapatkan hasil belajar siswa yang baik maka tenaga pendidikan harus mempunyai strategi dalam melakukan pembelajaran. Strategi merupakan pola umum rentetan kegiatan yang harus dilakukan untuk mencapai tujuan (Asril dalam Jurnal Pendidikan Fisika Indonesia yang ditulis oleh Hatika, 2016:113). Berdasarkan permasalahan yang terjadi di kelas VII SMP Islam Sudirman Ambarawa, peneliti beranggapan perlu adanya model pembelajaran yang tepat agar proses pembelajaran berjalan dengan efektif. Salah satu model yang dapat digunakan untuk mengatasi permasalahan dalam pembelajaran IPS adalah model pembelajaran Show And Tell. Model pembelajaran Show and Tell ini merupakan model pembelajaran yang kegiatannya menunjukkan sesuatu kepada audiens dan menjelaskan atau mendeskripsikan sesuatu itu. Hal ini sesuai dengan kebiasaan peserta didik yang suka menceritakan benda yang dimilikinya terhadap temannya. Selain itu, dilihat dari sarana dan prasarana yang ada di sekolah mampu mendukung adanya penelitian ini. Ruang kelas yang cukup luas, papan tulis, meja, dan kursi yang digunakan peserta didik sangat mendukung dan sesuai dengan model pembelajaran yang digunakan dalam penelitian ini. Dengan demikian, model show and tell ini dapat digunakan di SMP Islam Sudirman Ambarawa untuk membantu peserta didik dalam memahami materi lebih cepat karena materi dibawakan atau diceritakan oleh temannya sendiri dengan menggunakan bahasa mereka sendiri sehingga akan lebih mudah dipahami. Oleh karena itu, maka peneliti ingin melakukan penelitian dengan judul "Efektivitas Model Pembelajaran Show and Tell Terhadap Hasil Belajar IPS Siswa Kelas VII SMP Islam Sudirman Ambarawa".

\section{METODE}

Metode yang digunakan dalam penelitian ini adalah metode eksperimen semu (Quasi Experiment). Desain ini mempunyai kelompok kontrol, tetapi tidak dapat berfungsi sepenuhnya untuk mengontrol variabelvariabel luar yang mempengaruhi pelaksanaan eksperimen. Quasi Experimental Design digunakan karena pada kenyataannya sulit mendapatkan kelompok kontrol yang digunakan untuk penelitian (Sugiyono, 2015:114).

Desain penelitian yang digunakan dalam penelitian ini adalah Nonequivalent Control Group Design. Menurut Sugiyono (2015:116), 
dalam penelitian ini akan terdapat dua kelompok yang tidak dipilih secara random. Kedua kelompok tersebut kemudian diberi pretest untuk mengetahui keadaan awal adakah perbedaan antara kelompok eksperimen dan kelompok kontrol. Hasil pretest yang baik bila nilai kelompok eksperimen tidak berbeda secara signifikan. Desain Nonequivalent Control Group Design ditunjukkan pada Tabel 3.1 sebagai berikut

Tabel 3.1 Desain Penelitian Non-equivalen Control Group Desain

\begin{tabular}{lll}
\hline Sumber & $\begin{array}{l}\text { Kelas } \\
\text { Eksperimen }\end{array}$ & $\begin{array}{l}\text { Kelas } \\
\text { Kontrol }\end{array}$ \\
\hline $\begin{array}{l}\text { Jumlah } \\
\text { siswa }\end{array}$ & 32 & 32 \\
$\begin{array}{l}\text { Nilai rata- } \\
\text { rata }\end{array}$ & 4,25 & 4,12 \\
Nilai & 6 & 7 \\
tertinggi & & \\
Nilai \\
terendah \\
(Sugiyono, 2015:116)
\end{tabular}

Populasi dalam penelitian ini adalah seluruh peserta didik kelas VII SMP Islam Sudirman Ambarawa, tahun pelajaran 2018 yang terdiri dari tujuh kelas. Pada penelitian ini dari tujuh kelas terpilih satu kelas sebagai kelas eksperimen yaitu kelas VII G dan satu kelas sebagai kelas kontrol yaitu kelas VII C.

Alat pengumpul data yang akan digunakan dalam penelitian ini adalah tes dan dokumentasi.

\section{HASIL DAN PEMBAHASAN}

Hasil penelitian yang telah dilaksnaakan di SMP Islam Sudirman Ambarawa pada tanggal 05 Februari S.d. 03 Maret 2018, tentang Efektivitas Model Pembelajaran Show and Tell Terhadap Hasil Belajar IPS Siswa Kelas VII SMP Islam
Sudirman Ambarawa, akan diuraikan berdasarkan hasil analisis uji perbedaan ratarata kelas eksperimen dan kelas kontrol sebagai gambaran umum untuk membedakan hasil belajar IPS siswa antara kelas yang menggunakan model pembelajaran show and tell (kelas eksperimen) dengan yang menggunakan metode ceramah (kelas kontrol).

Dalam penelitian ini, pengukuran hasil belajar kognitif siswa dilakukan dua kali, yakni sebelum perlakuan dan setelah adanya perlakuan. Tes sebelum perlakuan dimaksudkan untuk melihat dan memastikan dua kelompok sampel terpilih sebelum perlakuan dalam kondisi homogen. Hasil belajar siswa sebelum perlakuan dapat dilihat pada Tabel 4.1 berikut.

\section{Tabel 4.1 Hasil Belajar Pretest}

\begin{tabular}{llll}
\hline & $\mathrm{O}_{1}$ & $\mathrm{X}$ & $\mathrm{O}_{2}$ \\
& $\mathrm{O}_{3}$ & - & $\mathrm{O}_{4}$ \\
\hline
\end{tabular}

untuk mengetahui hasil belajar siswa dalam ranah kognitif kelas eksperimen dengan menggunakan model pembelajaran show and tell dan kelas kontrol dengan menggunakan model ceramah, maka diukur dengan melakukan posttest. Gambaran umum mengenai hasil belajar kognitif dengan posttest dapat dilihat pada Tabel 4.2 berikut.

\section{Tabel 4.2 Hasil Belajar (Posttest)}

\begin{tabular}{|c|c|c|}
\hline \multirow[t]{2}{*}{ Sumber } & Kelas & Kelas \\
\hline & Eksperimen & Kontrol \\
\hline $\begin{array}{l}\text { Jumlah } \\
\text { siswa }\end{array}$ & 32 & 32 \\
\hline $\begin{array}{l}\text { Nilai } \\
\text { rata-rata }\end{array}$ & 7,25 & 6,31 \\
\hline $\begin{array}{l}\text { Nilai } \\
\text { tertinggi }\end{array}$ & 10 & 9 \\
\hline $\begin{array}{l}\text { Nilai } \\
\text { terendah }\end{array}$ & 6 & 4 \\
\hline
\end{tabular}


Untuk mengetahui perbedaan hasil belajar yang didapat melalui rata-rata posttest kedua kelas, maka dilakukan Uji Independent T-Test. Dalam penelitian ini, Uji Independent $T$-Test digunakan untuk menguji beda ratarata hasil belajar kognitif antara kelas eksperimen dan kelas kontrol. Dari hasil analisis Uji Independent T-Test dengan bantuan SPSS 16, diperoleh t hitung sebesar 3,132 dan $t$ tabel pada taraf signifikasi $5 \%$ dengan $N(32+32-2)=62$ adalah 1,66, sehingga $\mathrm{t}$ hitung $>\mathrm{t}$ tabel maka Ho ditolak dan Ha diterima. Ini menunjukkan bahwa terdapat perbedaan hasil belajar yang signifikan antara kelas yang menggunakan model pembelajaran show and tell dibandingkan dengan kelas yang menggunakan ceramah dalam pembelajaran IPS dengan materi Kegiatan Ekonomi. Dari data tersebut juga menunjukkan bahwa ratarata hasil belajar kelas eksperimen adalah 7,25 , dari rata-rata tersebut secara umum rata-rata hasil belajar kelas eksperimen telah melampaui KKM (Kriteria Ketuntasan Minimal) yakni sebesar 6,70. Ini lebih baik dibandingkan dengan kelas kontrol dengan rata-rata hasil belajar 6,31 yang belum melampaui KKM secara umum. Dengan demikian dapat disimpulkan bahwa efektivitas model pembelajaran show and tell terhadap hasil belajar IPS siswa kelas VII SMP Islam Sudirman Ambarawa, materi Kegiatan Ekonomi lebih efektif dibandingkan dengan model pembelajaran secara ceramah.

\section{Hasil belajar IPS peserta didik dengan menggunakan model pembelajaran show and tell}

Dari hasil olah data mengggunakan Uji paired sample T-Test dengan bantuan SPSS 16. menunjukkan pada kelas dengan menggunakan model pembelajaran show and tell, hasil belajar kognitif peserta didik pada tes sebelum perlakuan menunjukkan angka ratarata 4,25 , dengan nilai terendah 1 dan nilai tertinggi 6. Hasil tes setelah perlakuan menunjukkan angka 7,25 , dengan nilai terendah 6 dan nilai tertinggi 10. Hal ini menandakan bahwa hasil rata-rata kelas telah melebihi KKM mata pelajaran IPS yakni 6,70. Dengan demikian dapat disimpulkan bahwa hasil belajar IPS peserta didik kelas VII SMP Islam Sudirman Ambarawa, yang menggunakan model pembelajaran show and tell pada materi Kegiatan Ekonomi mengalami peningkatan sebesar 3,00 dan dapat mencapai KKM (Kriteia Ketuntasan Minimal). Husamah dan Setyaningrum (2013:169) menyatakan bahwa pembelajaran yang dilaksanakan haruslah dilakukan dengan tetap memperhatikan suasana belajar yang menyenangkan. Suasana yang menyenangkan dan tidak diikuti suasana tegang sangat baik untuk membangkitkan motivasi untuk belajar. Dengan adanya motivasi belajar pada diri peserta didik yang tinggi maka mutu hasil belajar pun akan menjadi tinggi.

Menurut tim Teacheranitores dalam Musfiroh (2011:8) menyatakan bahwa show and tell merangsang anak untuk berminat pada lingkungannya, lebih mengenal orang lain dan atribut di sekelilingnya. Hal ini mendorong anak untuk memiliki rasa tanggung jawab sosial. Sesuai dengan tujuan utama IPS ialah untuk mengembangkan potensi peserta didik agar peka terhadap masalah sosial yang terjadi di masyarakat, memiliki sikap mental positif terhadap perbaikan segala ketimpanganyang terjadi, dan terampil mengatasi setiap maslaah yang terjadi sehari-hari, baik yang menimpa dirinya sendiri maupun yang menimpa masyarakat (Trianto, 2013:176). Dengan demikian model pembelajaran show and tell efektif digunakan dalam pembelajaran IPS 
karena proses pembelajaran yang menyenangkan sehingga meningkatkan motivasi belajar peserta didik yang berpengaruh pada peningkatan hasil belajar peserta didik.

\section{Hasil belajar IPS peserta didik dengan menggunakan ceramah}

Dari hasil olah data mengggunakan Uji paired sample T-Test dengan bantuan SPSS 16. menunjukkan pada kelas dengan menggunakan ceramah, hasil belajar kognitif peserta didik pada tes sebelum perlakuan menunjukkan angka rata-rata 4,12, dengan nilai terendah 1 dan nilai tertinggi 7. Hasil tes setelah perlakuan menunjukkan angka 6,31 , dengan nilai terendah 4 dan nilai tertinggi 9. Hal ini menandakan bahwa hasil rata-rata belum melampaui KKM mata pelajaran IPS yakni 6,70. Dari data tersebut peningkatan hasil belajar peserta didik sebesar 2,19. Hal ini menunjukkan peningkatan hasil belajar peserta didik dengan menggunakan ceramah lebih rendah dibandingkan dengan yang menggunakan model pembelajaran show and tell. Dengan demikian dapat disimpulkan bahwa hasil belajar IPS peserta didik kelas VII SMP Islam Sudirman Ambarawa, yang menggunakan ceramah pada materi Kegiatan Ekonomi mengalami peningkatan sebesar 2,19 dan belum mencapai KKM (Kriteia Ketuntasan Minimal). Hal ini menunjukkan bahwa peningkatan hasil belajar IPS yang menggunakan ceramah lebih rendah dibandingkan dengan yang menggunakan model pembelajaran show and tell. Ini disebabkan karena menurut Husamah dan Setyaningrum (2013:168) menyatakan bahwa banyak orang beranggapan bahwa berbagai strategi pembelajaran inovatif termasuk PAIKEM sering kali tidak efisien (memakan waktu) lebih lama dibandingkan dengan pembelajaran tradisional/ konvensional. Hal tersebut menandakan bahwa pembelajaran ceramah ini tidak terlalu memakan waktu yang lama dalam pembelajaran. Namun hasil belajar yang diperoleh berbeda dengan hasil belajar yang menggunakan model pembelajaran show and tell.

Perbedaan hasil belajar IPS peserta didik yang menggunakan model pembelajaran show and tell (kelas eksperimen) dan yang menggunakan ceramah (kelas kontrol)

Dalam penelitian ini, untuk mengetahui efektivitas model pembelajaran show and tell, hasil rata-rata data posttest dibandingkan dan dihitung mengggunakan Uji independent sample T-Test dengan bantuan SPSS 16. Hasil hitung menunjukkan $\mathrm{t}$ hitung sebesar 3,132 dan $\mathrm{t}$ tabel pada taraf signifikasi $5 \%$ adalah 1,66 , sehingga t hitung $>\mathrm{t}$ tabel maka Ho ditolak dan $\mathrm{Ha}$ diterima. Ini menunjukkan bahwa terjadi perbedaan hasil belajar yang signifikan antara kelas yang menggunakan model pembelajaran show and tell dibandingkan dengan kelas yang menggunakan model ceramah dalam pembelajaran IPS dengan materi Kegiatan Ekonomi. Dari data tersebut juga menunjukkan bahwa rata-rata hasil belajar kelas eksperimen adalah 7,25, dari rata-rata tersebut secara umum rata-rata hasil belajar kelas eksperimen telah melampaui KKM (Kriteria Ketuntasan Minimal) yakni sebesar 67,00 . Ini lebih baik dibandingkan dengan kelas kontrol dengan rata-rata hasil belajar 6,31 yang belum melampaui KKM. Dengan demikian dapat disimpulkan bahwa efektivitas model pembelajaran show and tell terhadap hasil belajar IPS siswa kelas VII SMP Islam Sudirman Ambarawa, materi Kegiatan Ekonomi lebih baik dibandingkan dengan 
model ceramah. Dari hasil hitung tersebut dapat disimpulkan bahwa model pembelajaran show and tell lebih efektif dalam meningkatkan hasil belajar IPS siswa kelas VII SMP Islam Sudirman Ambarawa dibandingkan dengan model ceramah. Perbedaan hasil belajar IPS antara kelas eksperimen dan kelas kontrol dipengaruhi oleh dua faktor, yaitu faktor internal dan faktor eksternal. Wahab (2015:26) menyatakan bahwa faktor-faktor yang mempengaruhi belajar terdapat dua macam, yaitu faktor internal dan eksternal. Untuk itu, model pembelajaran show and tell tidak berpengaruh secara mutlak dalam penelitian ini. Model pembelajaran show and tell hanya sebagai stimulus agar faktor-faktor yang berpengaruh terhadap hasil belajar maksimal.

\section{SIMPULAN}

Berdasarkan hasil penelitian efektivitas model pembelajaran show and tell terhadap hasil belajar IPS siswa kelas VII SMP Islam Sudirman Ambarawa yang dilakukan oleh peneliti dapat disimpulkan bahwa pembelajaran IPS dengan menggunakan model pembelajaran show and tell efektif digunakan. Hal ini dibuktikan dengan telah tercapainya beberapa indikator ketuntasan meliputi: hasil posttest rata-rata kelas eksperimen sebesar 7,25. Selain itu dibuktikan dengan hasil perhitungan uji $\mathrm{t}$ diperoleh nilai $\mathrm{t}$ hitung sebesar 3,132. Sedangkan $\mathrm{t}$ tabel dengan taraf signifikasi 5\% dan $\mathrm{df} 1=1, \mathrm{df} 2=62$ adalah 1,66 . Sehingga $\mathrm{t}$ hitung $>\mathrm{t}$ tabel, maka Ho ditolak dan Ha diterima. Jadi rata-rata hasil belajar kelompok eksperimen lebih baik.

$$
\text { Pembelajaran IPS dengan }
$$

menggunakan ceramah kurang efektif. Hal ini dibuktikan dnegan hasil belajar rata-rata kelas kontrol yaitu 6,31 yang belum mencapai KKM. Sedangkan KKM yang ditetapkan di SMP Islam Sudirman Ambarawa yaitu 6,70.

Terdapat perbedaan hasil belajar IPS pada materi pokok Kegiatan Ekonomi pada kelas eksperimen dan kelas kontrol. Hasil hitung statistik menunjukkan $\mathrm{t}$ hitung $>\mathrm{t}$ tabel, sehingga $\mathrm{H}_{\mathrm{a}}$ diterima. Dengan demikian, dapat disimpulkan bahwa model pembelajaran show and tell lebih efektif dibandingkan dengan ceramah. Terdapat beberapa alasan mengapa model pembelajaran show and tell lebih baik dibandingkan dengan ceramah. Pertama, model pembelajaran show and tell mampu meminimalisasi aktivitas guru untuk menyampaikan pesan secara verbal. Kedua, model pembelajaran show and tell disajikan dalam bentuk cerita yang disampaikan secara sistematis oleh setiap kelompok peserta didik yang maju. Ketiga, model pembelajaran show and tell memberikan pengalaman baru kepada peserta didik, sehingga tercipta suasana belajar yang menyenangkan.

\section{DAFTAR PUSTAKA}

Hatika, R.G. 2016. "Peningkatan Hasil belajar Fisika Dengan Menerapkan Model Pembelajaran Advance Organizer Berbantu Animasi Komputer". Pendidikan Fisika Indonesia. No. 2. Hal. 113-117.

Husamah, dan Yanur Setyaningrum. 2013. Desain Pembelajaran Berbasis Pencapaian Kompetensi Panduan dalam Merancang Pembelajaran untuk Mendukung Implementasi Kurikulum 2013. Jakarta: Prestasi Pustakaraya.

Musfiroh, Takdirotun. 2011. "Show and Tell Edukatif Untuk Pengembangan Empati, AfiliasiResolusi Konflik, Dan Kebiasaan Positif Anak Usia Dini". Kependidikan. No. 2. Hal. 129-143.

Sapriya. 2009. Pendidikan IPS Konsep dan Pembelajaran. Bandung: Remaja Rosdakarya.

Sugiyono. 2015. Metode Penelitian Pendidikan. Bandung: Alfabeta. 
Fina Wasini, dkk / Sosiolium 1 (2) (2019)

Trianto. 2013. Model Pembelajaran Terpadu: Konsep, Strategi, dan Implementasinya dalam Kurikulum Tingkat Satuan Pendidikan (KTSP). Jakarta: Bumi Aksara.

Wahab, Rohmalina. 2015. Psikologi Belajar. Jakarta: Rajawali Pers. 